Humboldt Univercity Institute of Asian and African Studies

Post doc Dr. Gözde Özelce

Hausvogteiplatz 5-7 Room:314

10117 Berlin

\title{
Female Sufi Leaders in Turkey : Signals of A New Social Pattern Emerging in Seculer Side.
}

Two sufi women take part in activities related to sufism and create an attraction point in the secular side in Turkey.The most striking point is that both women do not wear headscarves although they are muslim women. This article attempts to show how sufi women Cemalnur Sargut and Hayatnur Artiran have idealized a Muslim woman's identity, the work they are doing to achieve this ideal, their attidue toward Rebublic values, and the effects of these attidues on their followers. This article was created from my doctoral thesis and based on Qualitative research which has been established on the basis of 2-year long participant observation and data obtained from in-depth and focus interviews. 31 women and 20 men were interviewed in depth and focus interviews.The main conclusions of my qualitative research are that the influence of theese sufi women is related with process of modernization by accelerating the establishment of the republic in Turkey. It seems that a perception has established concerning that "public apparency" of woman will disappear if the "apparency of body" disappears and the woman will return to its role which had relapsed into silence for centuries. Besides not using the headscarf, religious conversation have been created by theese sufi women in the balance of religion, philosophy and science and the fact that they are conducting their works under secular institutions such as foundations and associations have also been observed to have a very important effect on seculer side.

Key words: Sufi women, multiple modernity,secularism,muslim women identity 


\section{Introduction}

After the fall of the Ottoman Empire, under the leadership of Mustafa Kemal Ataturk founded the Republic of Turkey, it has brought western-style modernization. One of the most important influences on the women of the Republican revolutionaries(Kemalist project) was the removal of the headscarf. Not using the headscarf was an important demonstration of the "republican" image of women. Therefore, for many years in Turkey, Atatürk and religious discrimination is ongoing. As a response the headdress, educated and pious social class opposing to the modern woman image presented by Kemalist modernization, is it possible that a new and pious class that strives to exist by cooperating, not protesting against the Kemalist project being created? Is this emergent class strictly-devoted to the principles of Kemalism; or does it hold the power to transform Kemalism by using their right to criticize Kemalism from certain viewpoints and within that context, are they fabricating alternative answers to the question of modernity? These are some of the research questions that will be examined for any possible answers. Eisenstadt's multiple modernity concept, with its criticism on west-oriented modernism, lays the basis for the theoretical foundation of our study. Driven from the belief that there may exist different modernity forms in dissimilar geographies, we argue that the transformable piety and modernity conceptions of the outwardlysecular people in Turkey exemplify the model of multiple modernity on this geography. Within the context of our research, it is thus the aim of this paper to attempt to construe the way how the secularity and modernity perceptions of the secular social class in the largest metropolis of Turkey, Istanbul, have recently changed as an effect of the rising popularity of Sufism (Tasavvuf) most evidently symbolized in the teachings of these two sufi women.

Sociology of religion studies in Turkey structured on the tension between secular /pious or Islam and modernism have essentially focused upon the ways pious section, heavily decorated with Islamic tenets, was transformed/being transformed in its daily practices throughout the ongoing modernization process. The analyzed social section of which ongoing transformation is aimed to track in this paper stands before us as a social sect in whose daily life practices it is feasible to see the domination of secular tendencies on one hand while on the other hand they are in an attempt to increase their everyday religious practices. Hence, this class displays a clear model of the ambiguous character of the distinction between secular-pious from the perspective of opposite party.

What are the common points of these sufi women and how have they succeeded in influencing the secular side in Turkey? The answer to this problem must be sought in the process of modernization by accelerating the establishment of the republic in Turkey. In this regard, we focus on the change that Sufi women created in the secular side( living in İstanbul) and put forth the reasons of these changing regarding with multiple modernity and seculer theory arguments.

\subsection{Theoratical Aprroach: Multiple Secularization: Is it under the umbrella of Eclectic Paradigm or not?}

The fact that this phenomenon is at an important axis of modernity debates brings us to the question of how the research group we have studied might have been affected by these dynamics in the 
processes of Turkish modernization. Currently one of the most heavily discussed topics in social sciences is related to the crises nonwestern geographies experimented during modernization process and in consequence of broken crises the way modernity redefined its essence and emergent need to provide a variety of modernity definitions. Indeed, what should be the definition of modernity? Or, why has modernity perception always evolved on the basis of "Western-centered" descriptions? Eisenstadt argues that nowadays "obsession with the modernity and modernization is the most irresistible and common passion of our modern world" ${ }^{1}$ and he defines modernization attempts of all nations as "a cobweb they are trapped in"2 and he also attempts to analyze consequential social problems such as disorder, transformation, and protests. Indeed the cause and effect relation that Taylor sets between multi definitions of modernity and discrepancy between cultural and a-cultural theory opens up a new perspective. Cultural theory looks at modernity from the perspective of cultural relativism, and follows a hermeneutics approach so as to grasp to some extent the projections of historical process that nonwestern cultures experienced. However despite its initial objective this approach now tries to interpret the conflicts of a-cultural theory and states that; ' Failure to comprehend the array that is formed by the alternative modernities being molded in different parts of the world! This failure locks us inside an ethnocentric prison, without realizing the consequences of our own deeds, it condemns us to project our formations on everyone else' ${ }^{3}$

Durakbaşa $^{4}$ states that "Gemeinschaft", and "Geselshaft" concepts of Tonnies are widely employed in European and Non-European regions alike to identify and clarify the stages of the process toward modernity. He also underlines ${ }^{5}$ that as societies move on a straight, uncurved and linear path they are delineated toward their journey to modernity with respect to varied levels of modernity such as "primitive", "traditional" or "developing societies" and as can be seen in this format, the concepts of "primitive" and "traditional" are put into the same basket and analyzed under the category of "sect".

In light of all these approaches, Eisenstadt contended that it was then time to move away from a "west-centered" definition of modernity and in his work "Multiple Modernities" he draws a detailed analysis of the topic. ${ }^{6}$ In reference to Eisenstadt's paper, Geoffroy remarked that the concept of multiple modernity points to a range of factors. Based on the premise that modernity and westernization are not identical- despite their historical kinship and continual role of reference for other modern visions- it should be recognized that western pattern of modernity is not the one and only model of "authentic" modernities. Concept of multiple modernities advocates that such modernities are not "static", and the concept continues to change. And in the modern age it can be best grasped within the framework of new changes such as the reemergence and reconstruction of religious dimension',?

\footnotetext{
${ }^{1}$ Samuel N. Eisenstadt, Modernization, Protest and Transformation, (trans. Ufuk Çoşkun), İstanbul, Dogu Batı Press, 2007, p.11.

${ }^{2}$ p. 11

3 Andrew Davison, Secularism and Modernity in Turkey, (trans.Tuncay Birkan), İletişim Publications, 2002, p. 81.

${ }^{4}$ Ayşe Durakbaşa, Halide Edip Turkish Modernity and Feminism, İstanbul, İletişim, 2002, p.77.

${ }^{5}$ p.77

${ }^{6}$. S.Noah Eisenstadt, "Multiple Modernities", Daedalus 129 (1): 1-30,2000, p:1 quot. Grace Davison "New Approaches in Religion Sociology: A Western Outlook." (trans.M. Akgül and İ. Çapcioğlu ),AÜIFD, C. XLVI, S 1 (2005): 201-214., p.215.

${ }^{7}$ Martin Geoffroy, "Religious Theorizing in Global Age: A Typological Analysis"' (trans.: Abdullah Özbolat), Firat University Theology Periodicals, 17/1, p.5-10
} 
Hence, in varying definitions of modernity, we came to grasp that "religion" phenomenon became a critical axis and religion and modernity are not essentially viewed at opposite poles. Eisenstadt in his study on multiple modernities quoted Geoffroy's perspective in that way. "It is my premise that in the passage from modern age to global age it played a major role because religion is a socio cultural factor operating outside the state circle." 8 Right at this point it is worth remembering Habermas's statement that we came to the end of a secular age and began to receive the signals of post-secular age. After having defined the role that religion now plays on the Western world and Western public spaces as "post secular".?

As we delve into secularization theories, we realize that in existing literature theories are examined under three main titles; classical paradigm, new paradigm and eclectic paradigm. The presence of a formation which is trying to interfere with the secular structure, not a finished secular process in society and which is struggling to refine the individual and public spheres is noteworthy ${ }^{10}$.Casanova brings the agenda as criticism the classical paradigm suggesting that modernity will end its presence in the public and private spheres of religion and the new paradigm which has never referred to the institutional dimension of religion and suggests that any modern theory that fails to include the presence of religion in public spheres will remain uncompleted. The main argument of this approach is being oppesed to the concept of secularization that religion and secularization can not compromise. ${ }^{11}$

Taylor treats phenomenon of religion and secularity not from a polarized approach but rather from an inter-transient perspective; it can thus be argued that he presents to us an expansion of multiple modernity within the framework of secularity. Taylor in his work that underlines the shift of modernity from western axis and assumes the presence of different modernities in different geographies implied that the course of secularity might differ variably. Also, he underpinned that just as the case of multiple modernities it could be feasible to witness "multiple secularities". ${ }^{2}$ Göle ${ }^{13}$ claimed that within discrepant national, cultural and religious contexts multiple secularisms existed and likewise in Turkey non western secularisms also co-existed. That view is in support of Taylor's stance and with the argument in favor of the need for novel secularization approaches. She thus simply evokes the former studies on the background of secularization in different geographies, the point that was ignored in Taylor's work. Indeed Andrew Davison treated secularism from a hermeneutic approach, and stated that today there has been a corresponding diversification in secularism perceptions as the multiple modernity approaches, and neither modernity nor secularism ' had a meaning that could reach beyond mankind's perception on their nature " 14 .

Once we recognize that all three categories were structured on the western history and the stages it went through during modernization process, it then becomes questionable whether or not we are in need of a novel secularization paradigm through which it is viable to analyze secularization

\footnotetext{
${ }^{8}$ p.5

${ }^{9}$ Peter Clarke, Sociology of Religion:Modern Advancements,( trans. İ.Çapçıŏlu), Ankara,İmge , Ankara, 2012,p.312.

${ }^{10}$ Casanova, p. 6.

${ }^{11}$ Özay, a. g. e., p. 197-204.

12 Nilüfer Göle, Secular and Religiously Eroded Borders, İstanbul,Metis Yay, 2012, p.11

${ }_{13}^{13}$ p.11.

${ }_{14}$ Davison, Secularism and Modernity in Turkey,p:76.
} 
phenomenon currently experimented in any given country or a conceptualization that can be opened under the umbrella of eclectic paradigm would be sufficient. The basic argument of eclectic paradigm is protesting against a secularization approach that advocates the incompatibility between religion and secularization. ${ }^{15}$ Since "multiple secularization" employs a dialectic approach that views religion and modernity not as opposite poles but as two reforming and transforming factors, we hold the belief that it should be analyzed under the category of eclectic paradigm. Multiple secularization approach would present to our sight some multiple demonstrations of religion and modernity transformations of eclectic paradigm in varied geographies.

\section{Metarials and Methods}

\subsection{The Sample}

In our Qualitative research analysis, the religious practices oriented toward Islam Sufism and in particular on the basis of Kemalism loyalty (the degree and description form of this loyalty is one of the research questions) annul the ideology of Kemalist project that religious rituals must be practiced in private sphere only; thereby unveiling the need of Muslim fraternity and within that sense the demand for real social cooperation and accompanying cooperative worshiping and the desire to lead such a religious lifestyle. What we are describing here is a homegeneous religious formation in terms of education and financial level and this formation seeks to practice Islamic worship rituals in everyday actions. Meeting under the foundations chaired by Sargut and Artiran, these disciples convene in the Umrah, Hajj or saint visits and also in Oct. 29 Republican Day celebrations organized by such foundations. Our research population consists of the followers united to attend public conferences and talks organized by these two sufis as well as the ihwan group(community of disciples) of each sufi woman individually.

- Age Range: Age grouping was performed under 40 years and over 40 years of age. 15 women under the age of 40,16 women over the age of 40 were interviewed. The number of males interviewed under the age of 40 is 3 and the number of males over 40 is 17.

- Education and Income Level: It is seen that all diciples consists of middle / middle upper income level and highly educated people. Only two of the 51 people interviewed stated that they were high school graduates.

\subsection{The Interview Scripts}

Sampling group to be analyzed in this thesis is composed of people who have been attending to Sargut's and Artıran's talks for minimum 2 years and members of ihwan(diciples) group. Religious tendencies of analyzed people have been examined with respect to variables of age, gender, income and education level. The research has been established on the basis of 2-year long observation

\footnotetext{
${ }^{15}$ Mehmet.Özay, Modernisation, Secularization and Religion Affairs in Modern Sociology, Marmara University Institute of Social Sciences, PhD Dissertation, İstanbul, 2006, p. 197-204.
} 
notes of participants and data obtained from in-depth and focus interviews. During the whole research process, 4 focus group and in-depth interviews with 51 follower have been implemented.

\section{Results}

\subsection{Distinction between Kemalism and Ataturkism}

In its original definition, laicism refers to the neutrality of state. ${ }^{16}$ In that sense laicism stands for the autonomy of political and financial order ${ }^{17}$ and can also be defined as the result of the secularization process ${ }^{18}$. Separating private and social life and disjointing the material and moral life in private and social categories, modernism forges its religious authority on the idea of guarding an individual's private life and accordingly it enables the establishment of a laic political organization. 19

In addition to the ones stating that laicism has a dual meaning, others analyze laicism from a different denotation in its second meaning. Termed as Laicism this denotation is described as an ideology ${ }^{20}$ actively opposing to any active role that any religious faith or institutions could play in personal and social life. Based on the fact that the first modernization experiment of the nineteenth century in Turkey and having gained unprecedented impetus with the advent of Republican Principles, it is worth noting that within that perspective laicism principle received heavy criticism due to top-down ${ }^{21}$ implementation of Kemalism. Nuray Mert stated that in proIslam groups one of the most effective reasons why Kemalism became a historical issue of conflict is unrelated to the secularism of Kemalism, but rather related to the laic format of secularism and its focus on the western modernist approach ${ }^{22}$. She also agreed with the categorization of Turkish laicism practices in the form of subordinating religion to state control within the framework of identity problem ${ }^{23}$ that emerged upon the identification of modernity with Westernism and

\footnotetext{
${ }^{16}$ Bakır Çağlar, "Big Problem of Laicism in Turkey ; On Laicism and Its Varied Meanings" İstanbul, Cogito 1994, p.114.

${ }_{17}^{17}$ Thomas Michael “A Catholic Outlook to Laicism”, İstanbul, Cogito, Issue:I, Yap1 Kredi Publications, 1994, p. 103.

${ }^{18}$ p. 104

${ }^{19}$ Nuray Mert, “Laicism Conflict and Political Islam”, İstanbul, Cogito ,Issue:I, YapıKredi,1994, p.92

${ }^{20}$ Michael, "A Catholic Outlook to Laicism", p.104.

${ }^{21}$ Mert, "Laicism Conflict and Political Islam", p.95.

22 p.101

${ }^{23}$ p.97
} 
democratic $^{24}$ issues. Mert's approach described above is significant since it possesses similar qualities with the approach of Sargut's and Arrtıran's disciples.

In the conducted focus group interviews, remarks of a female disciple in Sargut's ihwan exemplify the drawn distinction between Ataturk's views and Kemalist policies. While claiming that as a statesman and politician, Ataturk ordered not only righteous but also faulty actions as well. They also underlined that laicism policies implemented after his decease had no resemblance with Ataturk's ideology.

It is a pity that with the closedown of tekke and zaviye complexes (Islamic lodges and monasteries) in society, we are now imprisoned to useless coffee houses. Further to that Ottomans were always demonized but that is not something Ataturk wanted, unfortunately Kemalist mentality ripped off my ties and my linkage with Ottomans whom they always demeaned!!. I have full respect and gratitude for Ataturk, I don't feel to have any conflicts, but I am strongly against the Kemalist mentality having ripped off my tie with my past. (45 years old, female,teacher)

Ahmet Yaşar Ocak states that Kemalism was shaped on the basis of laicism approach and by dismembering Islam from state control, social spheres and legal system it imprisoned religion to the domains of social ethics, faith and worship merely and strictly subordinated faith to state control. ${ }^{25}$ We can thus realize that Ocak criticized Kemalism in terms of its laicism approach. At the end of this process, Ocak argues that a socially-isolated Islam, termed as ' 'Kemalist Muslimism'; became an alienated form of Islam strictly defined in terms of faith and prayer and reserved to one's personal consciousness. He continues that this was a degraded form of Islam that could also be viewed as a cult Muslimism. His remark points out that this form of Muslimism moved downward from elite class gradually to the commoners. He identifies this movement as the preliminary cause of the identity chaos currently prevalent in Turkey. 'Indeed since the past till present day Turkey Muslimism has been experimented an identity chaos because it is closest society to the western geography unlike other Islamic states and it is most likely that this chaos will be experimented for many years ahead. This chaos created as an effect of cultural shifts is indeed one of the longest-dated chaos in Turkish history." 26

In the same focus group interview, the attitude of another interviewee was as below:

I personally believe that Kemalists themselves are the ones who most vehemently destroyed the legacy of Ataturk because there is a scholastic-Ataturkism approach. That is why I am against Kemalism .... But after all, we can analyze Ataturk with his right and wrong deeds without fetishizing him. I agree that He is one of the national assets of this society, Turkish Nation.. (52 years old, male, manager)

In Ahmet İnsel's work as well the statements of this interviewee are echoed. Ahmet İnsel in one of the articles in his work, Depression of Turkish Society, defines the scholastic Ataturkism this

\footnotetext{
24 p.95

${ }^{25}$ Ahmet Yaşar Ocak, Turks, Turkey and Islam, İstanbul, İletişim Publications, 1999,p.68.

${ }^{26}$ p. 123
} 
interviewee expressed as a "secular religion"27. Pointing out that the state has two religions in Turkey İnsel continues such: "As a matter of fact, the state has two religions in Turkey. Officially, "Ataturkism" which has now embraced a fully-secular position and non-officially Islam religion. If all citizens in a nation are mandated to obey a doctrine or an ideology in appearance at least, that means this state cannot be regarded as a laic state. ${ }^{28}$ Ataman approaches the same issue from the basis of "civil religion" conceptualization, and notes that the attempts to forge a civil religion in Turkey was molded around the circle of Ataturk. In a setting where Ataturk poems were chanted in Islamic hymn format, and discourses such as "Give back Kaaba to Arabs give us Çankaya" were widespread since there was a deliberate struggle to create a civil religion. ${ }^{29}$

Hence on one hand our field study focuses on the recent transformation that "Kemalist Muslimism" in Ocak's case had experimented while on the other hand, this study attempts to find the clues of the transformation that the socially-isolated Muslimism approach been confined within the limits of personal consciousness but always pursuing a never-ending desire for a "sect" had then experienced.

Cemalnur Sargut in the detailed interview we had about Ataturk and laicism shared her stance as below.

Ataturk is a national value and I believe national values need not be discussed a lot, but should be protected. Ottomans is another national value. Ottoman literature and history are national values. And values should be analyzed within the conjecture of specific historical conditions. Did Ataturk act correctly or not? His action was correct but if only his measures had been even more powerful. He passed away so young. I believe if he had lived longer he would have taken appropriate measures in due time and reopen tekke and zaviye complexes. After his decease, others failed to take adequate measures... America is one country that most effectively solved this problem. Everyone is free to establish and live religious institutions. Everyone can freely share his views and worship as their faith orders, there is absolutely no intervention. The best relationship between the state and religion can be viewed there, it should be the model to take I assume.

As can be seen interviewees can make a radical distinction between Kemalism and respect toward Ataturk's ideology and they can even allege that Kemalism defamed Ataturk. It can thus be concluded that the distinction between Kemalism and Ataturk has been attributed to the malpractices in state policies followed upon the decease of Ataturk.

\footnotetext{
${ }^{27}$ Ahmet İnsel, Depression of Turkish Society, İstanbul, Birikim Publications, 2014 ,p.121

${ }^{28}$ P. 122

29 Fatmanur Dikmen, “A Talk on Civil Religion with Assoc. Prof. Kemal Ataman”Bülent Ecevit University Faculty of Theology Journal, Vol. 1, Issue 2, 2014, pp. 151-166. For detailed information on Civil Religion see, Kemal Ataman, Sacred Pillar of Being a Nation: Civil Religion, İstanbul, Sentez Publications, 2014.
} 


\subsection{Meaning of Headcarves}

Creatives one of the most important changes in Turkey's religious "woman" is emerged as a phenomenon. It is possible to say that since the 1980s women in religious circles have actively participated in social and political life. However, since these movements were often perceived by secular societies as an extension of political Islam, the polarized image of the Atatürkist-religious distinction continued to exist in these lands. The studies we have undertaken Cultural Islamic frame of the female Sufis, Cemalnur Sargut and H. Nur Artıran reveal the signals of a new religious pattern transformed by this polarized view.

How seculer side of Turkey experience modernity-religion dialectic recently? There is a critical question can be asked: Why the seculer women and man in Turkey prefer following especially these two sufi woman leader? İs it because these sufi woman do not use headdress altough they are a muslim women? Can it be the only reason? Not wearing the headscarf is a symbol of respect for the republican revolution and a western view. Hence, at the beginning of this change, it is important that these women are not wearing headscarves.

The explanation of Sargut in the issue of the headscarf is as follows:

Unlike what is asserted by most people; headscarf or veiling is not a distinctive sign separating the Muslim women from others; because, those conforming to the veiling in the eastern countries are not just the Muslim women and the women in other religions are also veiled... The fact that it is the wearing of Muslims is a separate thing; the fact that it is a feature belonging only to the Muslims is a completely separate thing. ${ }^{30}$

Sargut referring to the fact that headscarf was existent also before Islam specified in the versicle no. 31 of Nimbus Surah brings the following explanation: "In the versicle, "Take the headscarf on yourself' or 'Veil your head' is not said; because, the women of the Eastern countries have veiled their heads since the old times. Headscarf constituted a part of a worn cloth." ${ }^{31}$ Sargut stating that this versicle came in the fifth year of the Hegira due to the fact that the chest and dewlap of the women would remain open as a result of fastening their headscarves on their napes and hanging them down in the Days of Ignorance also cites that the versicle made and arrangement on the clothes of the Muslim women and it came in the issue of the fact that the scarf should not be hanged down to the back, but it should be hung down in a way that it will cover the open parts. ${ }^{32}$

It has been seen that the views of Hayat Nur Artiran are different from the approach of Sargut in this issue. While Sargut tells the reasons of not using the headscarf upon the versicles she interprets, Artıran finds the command of headscarf in the versicle certain. Artıran specifying that she was veiled until she was fifty-five says that she waived from her scarf for the purpose of attract the secular section to Islam:

The provisions of Koran could never be discussed. Whatever is written in Koran about headscarf is certain. Am I going to change

\footnotetext{
${ }^{31}$ Sargut, p. 155.

${ }^{32}$ Sargut, p. 155.
} 
the provisions of Koran after one thousand and four hundred years? I would like to ask the question to those saying "Why is your head not veiled?" Koran orders to obey to the commands with all provisions. All its provisions are commands. It is necessary to obey to all the provisions in Koran for him/her to call another one to account by saying "Why is your head not veiled?" Did you carry out all the provisions that you call me to account or insult me because I am not veiled?

It is seen that while Sargut bases her thoughts about headscarf on a different interpretation of the versicle no. 31 of Nimbus Surah, Artıran accepts that the provision of the versicle is certain, but she expresses that she does not use headscarf for the purpose of being able to meet the secular environment with Islam.

Then, what are the views of the followers of Sargut and Artıran in this issue? The conducted participant observation has detected that the fact that Sargut and Artıran do not use headscarf is a very important factor in the deep and focus group discussions. While a disciple states that they face with the tag of "easy Islam" as they do not wear headscarf, he/she tries to tell the emphasis that the morals are not related to the headscarf, to the revolutions on respect.it seems that Islamic way of purdah has been coded as a movement which will bring the communal position of women to pre-republican period. This is because it seems that a perception has established concerning that "public apparency" of woman will disappear if the "apparency of body" disappears and the woman will return to its role which had relapsed into silence for centuries. If we review the communal position of woman throughout the history not only in all religions but also in the Islamic front in terms of sex, the Muslim women are indebted to Atatürk along with the fact that we come across with a phenomenon of woman who may go out of the "house", almost only for 90 years and has been able to take place in the public space as a "human" and they are unduly attached to the revolutions of republic for the fear of losing this right which had been acquired after centuries..

\subsection{Meaning Of Women in Islam}

Normally, in İslamic literature there is a lack of Sufi women studies because generally they hide themselves behind the doors. Unlike, both are very extraordinary/ progressive sufi women who are "globally interconnected" by using social media channels. Both have a website/blog and facebook account and use this tools effectively. Besides that they take part in Tv programmes and newspaper and magazines. They not only target to increase the number of the followers but they also challenge stereotype of muslim woman has been served by media delibrately full in burqas, being stoned, not being educated and dominated by men. Second, they both well educated women.Sufi Sargut is a chemistry engineer and worked as chemistry teacher during 20 years.Sufi Artıran worked as manager in a private company for many years. Third, they have devoleped such a linguistic balancing science, philosophy and religion and represent in a secul $\mathrm{r}$ instutiion.

It has been observed during the study both in the religious conversations of Sargut and Artiran that they mention Hrh Fatima frequently and they see her as a role model. Sargut saying "Hrh Fatima is also a guide, whether they accept or not" and also the emphasis of Artiran as "the continuation of the Prophet's descendance from Hrh Fatima expresses the importance of woman in Islam by 
her" show the place of Hrh Fatima in these two women Sufis. Two women Sufis to frequently mention their reverence to Hrh Fatima brings to the mind the question symbolized by Hrh Fatima "What is the identity of Muslim woman".

While Shayegan emphasizes that this identity identifies with the definition of Sophia woman with the meaning of "wise" - especially in the Persian Islam-, he says that Hrh Fatima is called as "Junction of Nimbus" due to the fact that the descendance continues by her. Hrh Fatima being the birth of inner reality symbolizes the personality of Sophia and is the bearer of the image of mental individualization. ${ }^{33}$ However; it is necessary to say that the Islam lived in today's Islamic countries is very different from this approach. Sargut answers in the following way the question as "Should we seek the women just starting to drive car in Saudi Arabia in the existence of versicles limiting women in Islam":

All these things are related to tradition. Our religion never limits woman. Our Prophet supported Hrh Hatice to work and trade. He attended to the camel races with Hrh Ayşe. He said that Fiqh developed with Hrh Ayşe. Hrh Fatima is also a guide whether they accept or not. Our Prophet says "Fatima is like my reflection in the mirror and the only person I stand up when she comes." It is understood here that women are glorious and high; but we could not understand the value our Prophet gives them. ${ }^{34}$

Cemâlnur Sargut significantly underlines that the life and morals of Hrh Muhammad should be taken into consideration to be able to understand the position of women in Islam without falling into misinterpretations.

One of the issues brought to the agenda about woman in the Islamic side is the concept of "woman nature". How are the comments of Sargut and Artıran in this issue that has taken place as a discussion topic among the Islamic supporters and Western supporters in our modernization history? Both women Sufis have specified that women have a more different creation than men and the physical power deficiency of the woman is balanced with having a spiritually strong and compassionate structure. In other words; man has a physically strong creation and woman has a spiritually strong creation. Artıran has given the following answer to the question "Does this difference require the women to make their choice of profession according to their nature?"

I never become stereotyped; because, our Prophet has not stereotyped anything. The first nurses are the Muslim women going to the war with our Prophet during his Period. It is known that women went to war, healed the injuries of the soldiers, gave them psychological support and told hymns during his Period. Our Prophet did not tell them "No, just sit at your home". He told them "Come, but I do not want you to shield your delicate bodies in the same line with the men. Stay in the back lines." He wanting them to stay in the back lines is not because he despises them, but because he values them.

\footnotetext{
${ }^{33}$ Daryush Shayegan, Yaralı Bilinç: Geleneksel Toplumlarda Kültürel Şizofreni, İstanbul, Metis Publication, 2012, p. 107.

${ }^{34}$ Interview with Cemâlnur Sargut, Journal of Hürriyet, 23. Haziran. 2015.
} 
The approach of Sargut is in parallel, but she has an approach preferring the suggestion of some profession groups. "Woman has the mercy attribution of Allah. They are merciful and compassionate. It is more correct to select the professions convenient for these attributions. For instance; being a teacher or doctor is very convenient, because firstly mercy is at front in these professions. However the water has been created as a whole and gives life, women crowned with material and moral knowledge is a source of life for her surroundings." "35

Could we say that Sargut and Artıran give an appearance that refers to the "wisdom" side of the Muslim woman identity and setting an example in this issue with their studies staying far away from political Islam and examined under the cultural Islam roof? Do the "having an ideal and aims of being in action" being the main concepts in the human model drawn by Muhammed Ikbal keep these two Sufi women as the new bearers of the Sophia woman image in these soils? It is possible to say that the importance of the Sophia woman stance and the studies conducted by them will increase day by day in the struggle against Islamophobia and militant Pan-Islamism ${ }^{36}$ today in parallel to the idea that perfect human being, namely the ideal human being should also be a model human being so that s/he could transfer some things to the future with his/her ability of representation s/he will have. ${ }^{37}$

\subsection{The Studies Under the Name of the Foundation and the Association}

In parallel with Republican reforms, at the end of processes emerging after the abolishment of caliphate and closing of tekke \& zaviye complexes, the fracture experienced in religious life within both personal and institutional framework vividly stands before us as a reality of Turkey's modernization history. However just as we grasped that modernization process was not initiated with reforms, reformist approaches toward tekke and zaviye complexes were also echoed in reformists' reactions against the 'closing' of these complexes, hence it is evident that this issue did not become foregrounded for the first time during Reform age ${ }^{38}$. It should however be recognized that the radical decision on that issue was taken during the Republican Age and this historic clash experimented in religious life was one of the major stress points of religious transformations of which aftershocks are still on the rise even in present day. Hence this paper also examines the way the stress conducted by this stress point was responded by the sects of Sargut and Arttıran and within the perspective of the very first two female leader in modern Turkey and their disciples, the transformation tekke culture has been experiencing is also a critical issue to comprehend for their successors.

In-depth interview with Hayatnur Arttıran dwelt on the question "Once we had Republican reforms and annulment of tekke and zaviye complexes did we correspondingly lose our sect culture? Below is her answer:

\footnotetext{
${ }^{35}$ Sargut, Peygambere Sevdirilen Kadın, p. 129.

${ }^{36}$ Ahmet Albayrak, “İkbal’ de Dinamik İnsan Anlayışı”, Dîvân İlmî Araştırmalar, V. 2, 1998, p. 4.

${ }^{38}$ II. Constitutionalist Period was the very first time that the idea of closing Tekke complexes and tarikats (sects) started to be worded. At that time, two distinctive arguments were presented. The first argument was in favor of the abolishment of tekke complexes and tarikats while the second argument was in favor of reforming their structure.(see, Mustafa Kara, Modern tasavvuf(Sufism) through Texts İstanbul, Dergah Publications, 2015, p. 53).
} 
Not at all, I would never say such a thing, those who want to live Allah's faith in its true sense can always find a way to live it within their soul and spirit. The able ones had already experimented it in their soul and spread to others to live it as well. That was always the real aim; those with strong pillars -in Mevlevi faith they are named as, 's/he has a strong pillar' - or in other terms those with unshakable faith never forsake their practices. Frankly those with shakable faith are, no matter if tekke and zaviye complexes were still alive; would claim always the same, old story! It is possible to have lost a drop of blood, but that is nothing to exaggerate I believe.

During the interviews conducted with her ihwan (diciples), the views of disciples on closing tekke and zaviye complexes are, with a footnote on the necessity to close them due to then-existing circumstances, citizens highly respectful toward Republican reforms. "So long as it is not disoriented from the real aim, I believe it would function like a social cement uniting the members of each group in society'.(over 40 years of age, male,business man)

\begin{abstract}
Although officially closed, Tekke complexes always continued to live behind the scenes. If provided by competent scholars possessing a high level of awareness, trainings in tekke complexes would undoubtedly serve to raise intellectual and foresighted citizens to assist their fellow citizens. Why would not there exist official public Sufism schools and training centers open for all? In modern-age conditions, we are in urgent need of intellectual citizens in all senses.( 44 years old,female, doctor)
\end{abstract}

All of the interviewed disciples of Hayatnur emphasize the importance of tekke complexes to ensure social cooperation and collective experimenting of the spiritual life. However although they have been closed since 1925 in Republican Turkey, as known, they managed to continue their existence by adopting secular names (association, foundation) or conducting home meetings.

Sargut's and Arttıran's ihwan in general support the idea of revitalizing tekke complexes and present this argument while they hold deep esteem for Ataturk as footnoted. Ataturk's passionate statement below should be considered as one of the reasons why this is still a controversial issue. In Söylev (Discourse) Ataturk stated such: ''Effendis and my fellow citizens, you should all strongly believe that Republic of Turkey can never ever be the state for the rule of sheiks, dervishes, disciples or sectarians. The most correct, the most accurate tarikat(order) is the order of modern civilization. ${ }^{39}$. In line with this statement, the disciples were asked if supporting the reopening of tekke complexes would be perceived as disrespect toward Ataturk's legacy. Below is their response:

Of course not, what does it have to do with this? Right now why wouldn't we discuss in detail the reason 'they must be opened', explain 'why must be opened'

\footnotetext{
${ }^{39}$ Parla Taha, Atatürk's Discourses and Statements, Vol. 3, İstanbul, Deniz Press, 2008, p.217.
} 
and the role we play as role models by providing permanent contributions to that field, but by leaving behind our mission simply use Ataturk to put ourselves into a meaningless fight would make no sense. 'He closed them, he did wrong'. Why would we show disrespect to everyone and everything and Allah above all else? It was,after all, Allah's order and wish to see tekke and zaviye complexes closed? (48 years old, male, engineer)

Umm-u Ken'an Dervish Lodge which is the lodge of Ken'an Rifaî was in activity between the years 1908-1925 and it was opened for activities again as Cenan Education, Culture and Art Society on July $15^{\text {th }} 2000$ after the closure of lodges and zawiyas in 1925. The academic studies to be conducted in the restored lodge building are handled within the scope of Ken'an Rifaî Mysticism Studies Institute and attention is paid to the usage of the word "institute" instead of "lodge".

Sargut having an approach regarding the requirement of the rehabilitation of the lodges instead of closure continues. But she carry out her works with the channel of societies and associations. Sargut manages an international organization with the cooperation of TURKKAD and KERIM Association under the name of "Awards for Service to Friendly Islam" as of 2005 for the purpose of supporting the academic studies ${ }^{40}$ conducted in the area of Islam. ${ }^{41}$ The studies conducted in the issue of Islamic knowledge are introduced and awarded in national or international area via this organization. Regarding the academic studies, Sargut provided the establishment of "Ken'an Rifaî Distinguished Professorship on Islamic Studies" daises in North Carolina University Religious Research Department (2009) and Beijing University Advanced Human Sciences Institute (2011) and the establishment of Kyoto University Ken'an Rifaî Mysticism Research Center in 2015. ${ }^{42}$ As a result of her studies, Sargut attained the title of Voluntary Doctorate from Azerbaijan Eurasia International Research University. Sargut saying that her purpose is to establish Mysticism Institutes all over the world, meeting the world nations with the mystic face of Islam and to struggle with Islamophobia within this context also specifies that she aims to see Istanbul as the mysticism center of the world.

In parallel to this approach, Sargut ${ }^{43}$ established Kerim Association in 2013 and Mysticism Research Institute was activated in Uskudar University within the body of the studies of this association. She still works as Uskudar University President Assistant and lectures in Uskudar University. The mysticism doctorate and graduate curriculum program she has opened in Uskudar University of the Institute aims to meet the academic educational system fictionalized in western style with the Islamic morals. Sargut says the following in the iftaree meal during which she announced that the Institute was opened: "We are talking about a religious education not opened under the Faculty of Theology for the first time ${ }^{44}$ and this is a revolution, my friends. There, those who have not undergone a religious education in academic meaning, but who have been educated in engineering, medicine and social sciences will study the education of mysticism; because, we 
need the scientists trying to perform their works in the most correct way in moral terms after this moment." 45

Like Sargut, Hayat Nur Artıran also sustains her studies with the channel of societies and associations. Hayat Nur Artıran who works as the deputy president of "Swiss Mevlevis Society" whose headquarters is in Zurich is also a founder member of "Sufi Women Alliance for the African Union and World Peace" whose headquarters is in Algeria and which was established together by the African and European scientists. Also; Hayat Nur Artıran also serving in the International Mevlana Association Science Board and World Foundation for the Handicapped Trustees Board still continues her studies as the President of Sefik Can International Mevlana Education and Culture Association. As seen; both women guides perform their Islamic works under "secular institutions".

\subsection{Language balancing science, philosohy and religion.}

At this point; the question of whether the activities performed by two women guides under secular institutions also bring a secular language with itself or not gains meaning. The woman guides struggling for attracting the secular section to themselves should also examine the language they use. However; the starting point of this attraction is based on far before than the studies of Sargut and Artıran. The attitudes of Ken'an er Rifaî and Tahirü'l Mevlevî after the closure of sects has a great importance in terms of the fact that this attraction today forms the historical ground. In his book called Conversations, Ken'an er Rifaî says the following with the emphasis that those with the task of wakening the public should not only be competent in the spiritual knowledge, but also the material knowledge: "It is definitely necessary for a guide to know the knowledge you have to be able to gain you and make you believe."46

The attraction of people from all strata towards Ken'an er Rifâi ${ }^{47}$ is also existent in Tahirü'l Mevlevî. Sefik Can cites in the following sentences how he used his home in Aksaray as a conversation place:

The humble house of Tahirü'l Mevlevî in Aksaray Taskasap was like a lodge, everybody would come to there. Known university instructors, professors, poets and scholars would come. I even saw a princess coming from Egypt there. For instance; one day, a churchman came there. ${ }^{48}$

This commonality in the attraction of the intellectual environment towards Tahirü'l-Mevlevî and Ken'an Rifaî is important in terms of forming the historical background of the attraction of the secular environment towards Sargut and Artıran. Therefore; it seems possible to say that the projections of a movement whose seeds were spread in 1930s are lived today.

Ken'an Rifaî is qualified as "hunter" and this situation shows itself in the properties of the language used by Sargut in her conversations. Sargut who is a chemical engineer and retired from chemistry teaching specifies that mysticism and chemistry has common properties and she benefits from the

\footnotetext{
${ }^{45}$ Speech of Cemalnur Sargut, İstanbul, Adile Sultan Palace, 12. Temmuz. 2014.

${ }^{46}$ Sargut, Açık Denize Yolculuk, p. 241.

${ }^{47}$ Sargut, Açık Denize Yolculuk,.p. 198.

${ }^{48}$ Küçük, p. 45.
} 
science of chemistry in her mystic conversations. The mentioning of the science and religion balance by Muhammed Ikbal and Ken'an Rifaî seems to be continuing in the effort of Sargut for meeting the science of chemistry and the knowledge of mysticism in her conversations and interviews.

What is called as atom is in motion all the time and everything consists of atoms. It is so interesting that there is a positive energy in the middle and the negative energies in its surroundings rotate around that positive. However; because there is an orbit in the ellipse shape, they obligatorily bend in the middle like "Hu" when the two come to the beginning. If every atom in the body says "hu" to the beauty attribution of Allah, to the positive energy, what a nonsense and wrong thing it is to say that "There is no Allah". 49

The explanation of "Hu" invocation by Sargut within the science of physics as "Because there is an orbit in the ellipse shape, they obligatorily bend in the middle like "Hu" when the two come to the beginning" is due to the effort of meeting science and religion and more precisely, they are actually one. However; Sargut says "We are in a very lucky period in which it has been understood that science and religion say the same thing and science has reached perfection" and she frequently repeats this sentence in her conversations. Her tendency to use the arguments of the nature sciences due to the fact that she is a chemical engineer is an important factor of forming a secular language appearance. ${ }^{50}$ How is it interpreted by her followers that Sargut is using the science language?

Cemâlnur Hodja sometimes gives examples from this science because she is a chemistry teacher and this affects me so much. In her conversations, science and religion are not separate. I used to have a worry about I would be away from science if I were a religionist. These two met inside me anymore, and it could also be said that they became one inside me. (28 years old, female,master student).

I took lectures from Cemâlnur Sargut 20 years ago because she was a chemistry teacher. Questioning started in me also on the spiritual issues with the comparison of mysticism and chemistry during the lessons. I asked her any question I wanted and started to get satisfying answers to them. And in this way, I felt like I should go to her conversations. (47 years old, male, engineer).

A second factor in forming a secular language is reference to the Eastern and Western philosophers by both women guides in their conversations. The inclusion of the old Greek philosophers by both Sargut and Artiran in their mysticism conversations could be assessed as the impact of the Illuminationism school meeting the religion and philosophy. ${ }^{51}$ However; Sertarik Mesnevihan Sefik Can being the guide of Artıran wrote a book called Mevlânâ ve Eflatun and he tried to reveal the similar sides of both of them in this book. Although Sefik Can does not set off with the idea that Mevlânâ benefitted from Plato, he has specified that the works belonging to the great Greek

\footnotetext{
${ }^{49}$ Beyaz TV, Tv program with Cemâlnur Sargut , 4. Kasım.2 012.

${ }^{51}$ In the form of new Platoism, which is in close contact with the ancient Iranian and Egyptian philosophy, it is that we see in Farabi and Ibni Sina. Süleyman Uludağ, Íslam Düşüncesinin Yapısı, İstanbul, Dergâh Yayınları, 2015, s. 205.
} 
philosophers such as Plato and Aristotle have been translated into Arabic during the Abbasid Age and tries to mention the probability of this. ${ }^{52}$

In parallel to Sefik Can Hodja emphasizing the similarity of Plato and Mevlana, Sargut gives places to the following expressions in her conversations: "As said by Plato, here consists of shadows, we are the shadow players. In an age in which Islamic knowledge did not occur yet, Plato was the perfect human being within his own age." Likewise; Hayat Nur Artıran mentions the old Greek philosophers in her conversations and books and even compares Mevlana to Epictetus. Artiran specifying that Epictetus was not overwhelmed by his miseries and ambitions when he was a slave two thousand years ago and rose up to the summit point of his soul freedom ${ }^{53}$ expresses her thoughts in the following way: "Hrh Mevlânâ Celaleddin-i Rumi remembered as the sultan of the lovers of Allah all over the world, whose soul and body are free and the philosopher Epictetus living as a slave centuries before him said 'To be able to become free is not being able to do anything you want any time you want, but being able to save yourself from the captivity of various material pleasures and ambitions.", 54

\subsection{Modernism Criticism of Disciples}

How do the disciples of Sargut and Artıran whose commitments to the revolutions of Republic are apparent define the modernism? When it is considered that Turkey has a western style experience of modernization, it is possible to say that these disciples who have received a secular training have created a new modernity description within a blend of this pietism and modernism. In this part, we will examine the thoughts of disciples of Sargut and Arttıran about the western modernism and lifestyle brought along in order to find answer to these questions.

..... In my opinion, the modern life does not mean saying that modern life is in Europe and America and depriving themselves as many of us do (54 years old, female,teacher)

Along with that the criticism brought to the modernism are in this manner, are these disciples able to offer a new modernism understanding? How do they describe the moderns from an Islamic front? The lines that the disciples of Sargut who have obtained a Western style education and are bachelor and a great majority of whom have got a master degree, described the modern human are as follows:

The area where we will search for the modernity, is the Era of Bliss. The most modern period is that period. And in our opinion, the most modern human is the Prophet Muhammad.... (34 year old, female, engineer)

While another disciple states that they will be able to find the felicity when they get back to the Era of Bliss, he/she states that western style modernism destroys our culture.

\footnotetext{
${ }^{52}$ Şefik Can, Mevlânâ ve Eflatun, İstanbul, Kurtuba Publications, 2009, p. 18.

${ }^{53}$ Hayat Nur Artıran, Herkes Seni Terk Etse, Aşk Terk Etmez, İstanbul, Sufi Publication, 2014, p. 23.

${ }^{54}$ Artıran, p. 27.
} 
What you expect from a colonist mentality: bringing you into existence? It is a condition to make this return and make peace with our Islamic culture... How we will make a return to the Era of Bliss and how we will be moral with a prophet moral? We should think over that. ( 58 years old,male, journalist)

How this become possible that two generations who have been brought up with republican and secular values in Turkey, have a desire for making a return to the Era of Bliss and cite the Prophet Muhammad as the most modern while criticizing the western modernism? Which social, sociophysiological and maybe historical refraction points may have prepared this process? In this regard, the attitude of Gellner is also very stimulating. Gellner describes this as "going back home rather than denying itself" 55 . Gellner who characterizes the effect of westernization in Islamic communities as "trauma" states that Islamic communities have led to a serious stalemate since $18^{\text {th }}$ century along with desire of having an equal power with the western countries and they have been forced into making a choice between maintaining their traditions and becoming stronger financially and underlines that an agonizing process is experienced at the stalemate of making a choice. Gellner who says "like going back home morally rather than denying himself/herself" seems legitimate about "going back home".

\section{Final Discussion}

The women Sufis, Cemâlnur Sargut and H. Nur Artıran, reveal the signals of a new religious pattern in which the polarizing image of the distinction between Kemalist-religionist turned itself with their studies handled under the roof of Cultural Islam. This study trying to reveal what kind of a Muslim identity Sargut and Artıran idealizes, the studies they have conducted to realize this ideal and the impacts of these studies on the followers has both tried to reveal the reasons for the attraction by the secular environment to these two women Sufis and has tried to express the transformation it has undergone. This change we try to understand by using the arguments of the multiple modernity and secularization paradigms both blends the modern woman identity with Muslim woman identity and also indicates a new man identity transforming the modern woman image in their mind. Therefore; it is possible to say that the answer given to the question "What is modernity?" changing in the secular environment gives signals of a social pattern which change the modernity codes within the direction of both genders and which are new in the perceptions of religion and modernity. This is such a social pattern that two generations brought up with the secular codes could give the answer of "Hrh Muhammad" to the question "Who is modern?" and could define the most modern period as the Era of Bliss. This is such a social pattern that it demolishes the fact that religious rituals should be carried out in private areas by the Kemalist project, emphasizes the brotherhood of the believers and the social cooperation lived within this meaning and the need of worship as a crowd and wants to live the Islamic prays in daily life practices. As a result; this social pattern reveals a new way of behavior that could join together both in October 29th Republic ceremonies and in Kaaba and therefore, it forms a new religious social pattern in which the wrongness of artificial categorizations just like previously performed

${ }^{55}$ Ernest Gellner, Postmodernism,Reason and Religion, Newyork, Routlege, 1992, p. 84. 
Kemalist-religionist distinction are more visible. This new social pattern is an indicator of the existence of different modernization and secularization ways in non-western geographies.

"Need for ontological trust" mentioned in the modernism criticism of Giddens seems to be met in the mysticism conversations in which a spiritual guide shares the divine knowledge. It seems possible to see the search for a way of life by the secular individuals of Turkey in which they balance the positive sciences and spiritual knowledge as a coping strategy against the meaning crisis of modernity in a meaning. This situation brings to the mind the question "Will the guides fill in the place of the psychologist, psychiatrist or consultancy centers replacing some social security mechanisms defined by Giddens as 'disembedding mechanisms' in the post secular age anymore?" On the other hand; these conversations also meet the need for "congregation" as the places in which followers join together and socialize and the conducted interviews reveal the existence of this need. The crisis of meaning brought by modernity is tried to be terminated with the existence of a spiritual guide on one hand and with the cooperation and collaboration brought by the common ground of the feeling of "togetherness of believers" on the other hand. It seems possible to say that we witness the pains of the transition from guild to congregation at least in some parts of the secular section on these soils in parallel to the expression of Bauman "We miss congregation, because we miss the security which the world we live in could render much less and is more reluctant to covenant although it is the most important characteristic for a happy life",56 Could the selection of woman Sufis with secular appearance be an indicator for the fact that the Sufi woman leaders will gain importance day by day in the future in the process of "going back home" specified by Gellner?

In this article, new religious groups, religious orientations of the newly secular circles in Turkey and thus formed and examined their behavior patterns in exposed the religious "needs "has tried to emphasize strongly. This need strives to highlight the need for macro and mezzo policies and the institutional work to be created in this context, while demonstrating the limited presence of religious areas in which the secular sector can feel comfortable. On the other hand, it is thought that this research will open the door to new researches in this area in terms of emphasizing the effective role of women in religious education. ${ }^{56}$ Zigmund Bauman, Cemaatler. Güvenli Olmayan Bir Dünyada Güvenlik Arayışı, (çev. Nurdan Soysal), İstanbul,
Say Yayınları, 2016, s. 151. 


\section{BIBLIOGRAPH}

ALBAYRAK Ahmet, “İkbal'in Ruh Mimarı: Mevlâna”, 1997.

Artıran H. Nur, Herkes Seni Terk Etse Aşk Terk Etmez, İstanbul, Sufi Books, 2014.

Artıran H. Nur, Aşk Bir Davaya Benzer, İstanbul, Sufi Books, 2014.

Berger Peter, "Sekülerizmin Gerilemesi,Sekülerizm Sorgulanıyor", (Comp. \&Trans. A. Köse), İstanbul,Ufuk Press, 2002.

Can Şefik, Mevlânâ ve Eflatun, İstanbul, Kurtuba Books, 2009.

Casanova Jose, "Private and Public Religions. Social Research", V. 59, N. 1, 1992, pp. 17-57.

Clarke Peter, Sociology of Religion:Modern Advancements, Ankara, İmge, 2012.

Çağlar Bakır, "Big Problem of Laicism in Turkey ; On Laicism and Its Varied Meanings" İstanbul, Cogito 1994, p.114.

Davison Andrew, Secularism and Modernity in Turkey, (trans.Tuncay Birkan), İletişim Publications, 2002

Dikmen Fatmanur, "A Talk on Civil Religion with Assoc. Prof. Kemal Ataman"Bülent Ecevit University Faculty of Theology Journal, Vol. 1, Issue 2, 2014, pp. 151-166. For detailed information on Civil Religion see, Kemal Ataman, Sacred Pillar of Being a Nation: Civil Religion, İstanbul, Sentez Publications, 2014.

Durakbaşa,Ayşe, Halide Edip Turkish Modernity and Feminism, İstanbul, İletişim, 2002.

Eisenstadt Samuel , Modernization, Protest and Transformation , (trans. Ufuk Çoşkun), İstanbul, Dogu Batı Press, 2007.

Eisenstadt Samuel, "Multiple Modernities”, Daedalus 129 (1): 1-30,2000, p:1 quot. Grace Davison "New Approaches in Religion Sociology: A Western Outlook." (trans.M. Akgül and İ. Çapcıoğlu ), $A \ddot{U I F} D, C . X L V I, S 1$ (2005): 201-214.

Gellner Ernest, Postmodernism, Reason and Religion, Newyork, Routlege, 1992. 
Geoffroy Martin "Religious Theorizing in Global Age: A Typological Analysis', (trans. Abdullah Özbolat), Firat University Theology Periodicals, 17/1.

Göle Nilüfer, Secular and Religiously Eroded Borders, İstanbul,Metis Publication, 2012.

İnsel,Ahmet, Türk Toplumunun Bunalımı, İstanbul, Birikim Publications, 2014.

Kandiyoti Deniz, Cariyeler, Babalar, Yurttaşlar, Metis Yayınevi, İstanbul,2015.

Kara Mustafa, Din Hayat Sanat Açısından Tekkeler ve Zaviyeler, İstanbul, Dergâh Publications, 1999.

Kara Mustafa, Metinlerle Günümüz Tasavvuf Hareketleri, İstanbul, Dergâh Publications, 2014.

Küçük Sezai, Şefik Can Mevlânâ ile Bir Ömür, İstanbul, Sufi Books, 2011.

Mert Nuray, 'Laicism Conflict and Political Islam', İstanbul, Cogito ,Issue:I, YapıKredi,1994.

Michael Thomas "A Catholic Outlook to Laicism", İstanbul, Cogito, Issue:I, Yap1 Kredi Publications, 1994.

Ocak Ahmet Yaşar, Turkiye, Turkler ve Islam, İstanbul, İletişim Publications, 1999.

Özay Mehmet, Modernisation, Secularization and Religion Affairs in Modern Sociology, Marmara University Institute of Social Sciences, PhD Dissertation, İstanbul, 2006, p. 197-204.

Sargut Cemâlnur, Açık Denize Yolculuk, (haz. Sadık Yalsızuçanlar), İstanbul, Nefes Press, 2014.

Sargut Cemâlnur, Peygambere Sevdirilen Kadın, İstanbul, Nefes Press, 2011.

Sargut Cemâlnur, Sâmiha Ayverdi ile Sirra Yolculuk, İstanbul, Nefes Press, 2011.

Shayegan Daryush, Yaralı Bilinç: Geleneksel Toplumlarda Kültürel Şizofreni, İstanbul, Metis Press, 2012.

Taha Parla, Atatürk's Discourses and Statements, Vol. 3, İstanbul, Deniz Press, 2008.

Taylor Charles, Modern Social Visions, Metis Press., İstanbul, 2006.

Taylor Charles, Secular Age, ,̇̇stanbul, İş Bankası Kültür Books, 2014. 